\title{
RESEARCH ARTICLE \\ Effective Chemical Pretreatment for Recovery of Fermentable Sugars from pearl millet biomass
}

Maheshwari Packiam ${ }^{1}$ and Subburamu Karthikeyan 2.

${ }^{1}$ Department of Agricultural Microbiology, Tamil Nadu Agricultural University, Coimbatore 641003

2 Department of Bioenergy, Tamil Nadu Agricultural University, Coimbatore - 641003

\section{ABSTRACT}

Lignocellulosic plant material implies an untouched source of fermentable sugars for significant ethanol produc- tion. Pearl millet is potentially a viable feedstock for bioethanol production. The efficiency of Ortho-phosphoric acid, alkaline hydrogen peroxide, lime, and hydrothermal pretreatment as a potential chemical pretreatment on pearl millet was investigated in the present study. Based on the experimental results a mathematical model was developed for each pretreatment. Among the different pretreatment acid pretreated biomass showed highest sugar yield of $41.8 \mathrm{~g} / 100 \mathrm{~g}$ of biomass and inhibitor yield of $4.02 \%$. The raw biomass showed (34.76 \%) the lowest crystallinity index (Crl) because it has a higher content of hemicellulose and lignin, which are amorphous in nature. The specific surface area of acid pretreated biomass increased significantly and the $\mathrm{Crl}$ of the pretreated biomass apparently increased (75.79 \%) after the pretreatment. The main aim of pretreatment is to separate the hemicel- lulose and lignin for maximum recovery of fermentable sugars. Pretreated biomass was characterised by scanning electron microscope SEM and X-ray diffraction.

Keywords: Ortho-phosphoric acid, alkaline hydrogen peroxide, lime, hydrothermal pretreatment, pearl millet bio- mass

\section{INTRODUCTION}

Pearl millet (Pennisetumglaucum L.R. Br., Poa- ceae) is popularly known as bajra (cumbu) is one of the most extensively cultivated cereals in the world, after rice, wheat, and sorghum and particularly in arid to semi-arid regions. It is one of the important staple foods for about more than 500 million people in Asia and Africa and grows on $27 \mathrm{mha}$ (Amarender Reddy et al., 2013). Global production of its grain probably exceeds 10 million tons a year, to which India contrib- utes nearly half. Pearl millet is mainly cultivated for food, forage, fuel, mulch crop and as building materi- al. In India, the major pearl millet producing states are Rajasthan, Maharashtra, Haryana, Uttar Pradesh and Gujarat. Bajra requires low rainfall ranging between $40-60 \mathrm{~cm}$ and optimum temperature is $20-30^{\circ} \mathrm{C}$. It is also productive on acid soils. Pearl millet is an an- nual C4 grasses which thrives well in black cotton soil and sandy loam soil having well drainage system and yield a considerable quantity of straw after harvest which could be interesting alternatives to corn (Zea mays [L.]) for ethanol production. For optimal pearl millet requires 
approximately half of the water need- ed by maize or sorghum (Basavaraj et al., 2010). Pearl millet straw was not competing with primary food crop. Hence, these biomass were promising renew-able feedstock from biomass to bio-fuel. Pearl millet is one of the important feedstock for bio-fuel produc- tion, another advantage is that sweet sorghum and pearl millet are tropical originated plants and hence it has the potential as fuel feedstock. Pearl millet bio- mass composed of three major components such as cellulose, hemicellulose and lignin which are tightly bound each other. Among these compounds hemicel- lulose and cellulose is the polymers of sugars and can be hydrolyzed to form fermentable sugars. Cellulosic sugars are the primary currency of bioeconomy and can be further fermented into ethanol. Lignin is re- sponsible for integrity, structural rigidity prevention of swelling of biomass and can be formidable barrier for enzymatic saccharification. The complex structure of biomass suitable pretreatment method is required to release the fermentable sugar and prepare the bio- mass for enzymatic saccharification.

Materials and methods Sample preparation

This study was carried out on lignocellulosic bio- mass pearl millet variety ICMV 05222 procured from ICRISAT, Hyderabad. The feedstock was air dried to reduce the moisture content to 6-9\% and size of the straw used for experiment was in the range of 0.2 to

$10.0 \mathrm{~cm}$. The samples were stored in air tight poly-thene bag at room temperature throughout the ex- perimental studies to prevent the entry of moisture and other contaminants.

Analytical method

The proximate analysis of raw and pretreated sample viz., moisture content, ash, sugar recovery, lignin, cellulose and hemicellulose content was car- ried out according to the laboratory analysis protocol (LAP) of National Renewable Energy Laboratory (NREL), Colorado, USA (NREL, 2004).

Chemical pretreatment experiment

Chemical pretreatment was adopted to break down the structure of the lignocellulosic matrix to facilitate the bioconversion. The pearl millet biomass was pretreated with three different chemicals at dif- ferent concentration viz., ortho-phosphoric acid at 4, 8, 12, and $16 \%$, alkaline hydrogen peroxide at 1.2 ,

$1.8,2.4,3 \%$ and lime at $0.7,0.9$ and $1.1 \%$ using the solid loading of $7.5,10$ and $12.5 \%$ at different tem- peratures (for acid 100 and $121^{\circ} \mathrm{C}$, lime and alkaline hydrogen peroxide 80,100 and $121^{\circ} \mathrm{C}$ respectively) at different time interval (for acid 60, 120 and $180 \mathrm{~min}$, lime and alkaline hydrogen peroxide 60,90 and $120 \mathrm{~min}$ ). For alkaline hydrogen peroxide treatment, the $\mathrm{pH}$ was adjusted to 11.5 using sodium hydroxide. Com- bination of previously optimized chemical concentra- tion and total solids was carried at the temperature of 140,150 and $160^{\circ} \mathrm{C}$ and reaction time of 10, 20 and $30 \mathrm{~min}$. Based on the results modeling was developed for optimization of the acid, alkaline hydrogen peroxar release was estimated in the liquid sample using dinitrosalicyclic acid assay (DNSA method) according to the method of Miller, (1959). The byproducts and degradation products formed during the pretreat- ment were analyzed according to the modified method of Bray and Thorp (1954). The pearl millet biomass was characterized by SEM and XRD. Result

Proximate analysis of pearl millet biomass

The Proximate analysis of pearl millet biomass revealed that moisture $(8 \pm 0.32 \%)$, ash $(6.27 \pm 0.08 \%)$, total solids $(92 \pm 0.14 \%)$, water extractives $(6.43$ $\pm 0.12)$, ethanol extractives (5.72 \pm 0.34$)$, cellulose $(41.6 \pm 0.16 \%)$, glucan $(28.47 \pm 2.88 \%)$, galactan (17.24 \pm 0.46$)$, arabinan (3.78 \pm 0.04$)$, xylan $(5.12 \pm 0.46)$, acid insoluble lignin (16.32 \pm 0.49$)$ and acid soluble lig- nin $(5.49 \pm 0.08 \%)$. Based on the pretreatment experi- mental results a mathematical model was developed for acid, alkaline hydrogen peroxide, lime and hydro- thermal pretreatment and 
prediction of the amount of total reducing sugar yield.

The optimized parameters determined for acid (16\% ortho- phosphoric acid concentration, 12.5 per cent total solids loading, $121^{\circ} \mathrm{C}$ and $3 \mathrm{~h}$ ), alkaline hy-drogen peroxide ( $3 \%$ of alkaline hydrogen peroxide concentration, $10 \%$ total solids loading, $121^{\circ} \mathrm{C}$ and $\left.2 \mathrm{~h}\right)$, lime (1.1 per cent lime concentration, 7.5 per cent total solids loading, $121^{\circ} \mathrm{C}$ and $2 \mathrm{~h}$ ) and hydrothermal pretreatment (16\% ortho- phosphoric acid concen- tration, 12.5 per cent total solids loading, $160^{\circ} \mathrm{C}$ and ide, lime and hydrothermal pretreatment condition.

$10 \mathrm{~min}$. The highest total sugar yield of H PO $(41.8 \mathrm{~g} / 3 \quad 4$

The optimization of the pretreatment parameter has

been done using numerical optimization tool in statis- tical software package named Design Expert by using desirability function Design expert 9.0.6.2 (Stat-Ease, Inc.

Minneapolis, MN 55413).The optimum condition was selected based on the sugar release and inhibitor compounds for each pretreatment.

After each pretreatment, the pretreated bio- mass was separated from the liquid fraction by filtra- tion. The substrate (water insoluble fiber) was washed with distilled water until neutral $\mathrm{pH}$. The neutralized biomass was pressed manually to remove the water. The biomass was dried in an oven until the constant weight reached and the dried biomass was measured to determine the weight loss during pretreatment which corresponds to the lignin reduction percent- age and digestibility of other components. The sug-100 g of biomass), $\mathrm{H}_{2} \mathrm{O}_{2}$ (17.65 g/ $100 \mathrm{~g}$ of biomass), lime (22.88 g/ $100 \mathrm{~g}$ of biomass), hydrothermal $(0.11 \mathrm{~g} / 100 \mathrm{~g}$ of biomass.) was obtained in the optimized condition. The pretreated biomass was resulted in high $\mathrm{Crl}$ (60.84 to 75.94$)$ than in raw biomass (34.76\%).

\section{Discussion}

Lignocellulosic biomass consists of cellulose, hemicellulose, lignin, proteins, acids, salts and min- erals. The differences in composition of the biomass may be varies with season to season, location, soil type, plant to plant, maturity of the crop, method of harvest and storage, analytical procedure and size of the biomass.

However, when grown in different envi- ronmental condition significant variation may occur. Chemical composition is also one of the important factors for biofuel

production. $12.15 \%$ of total ex-

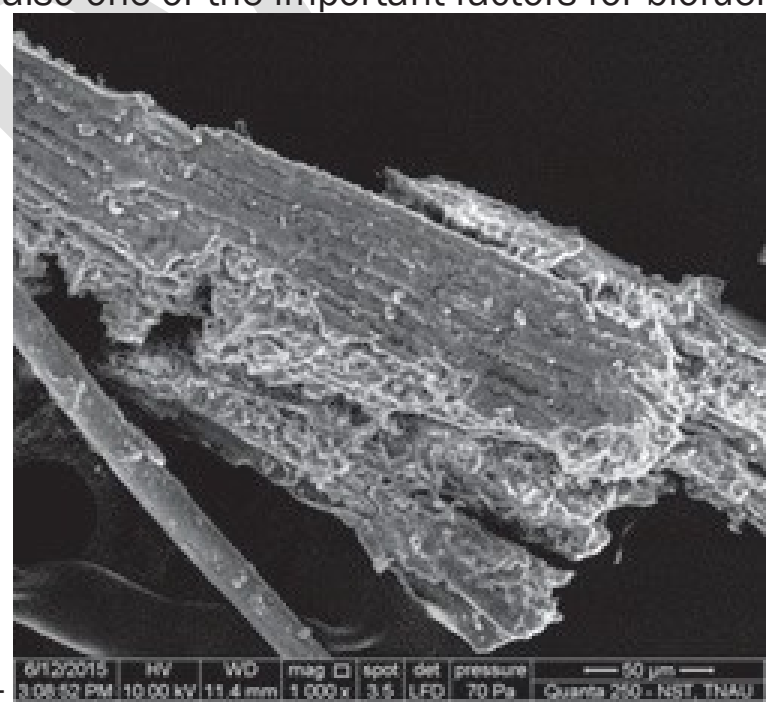




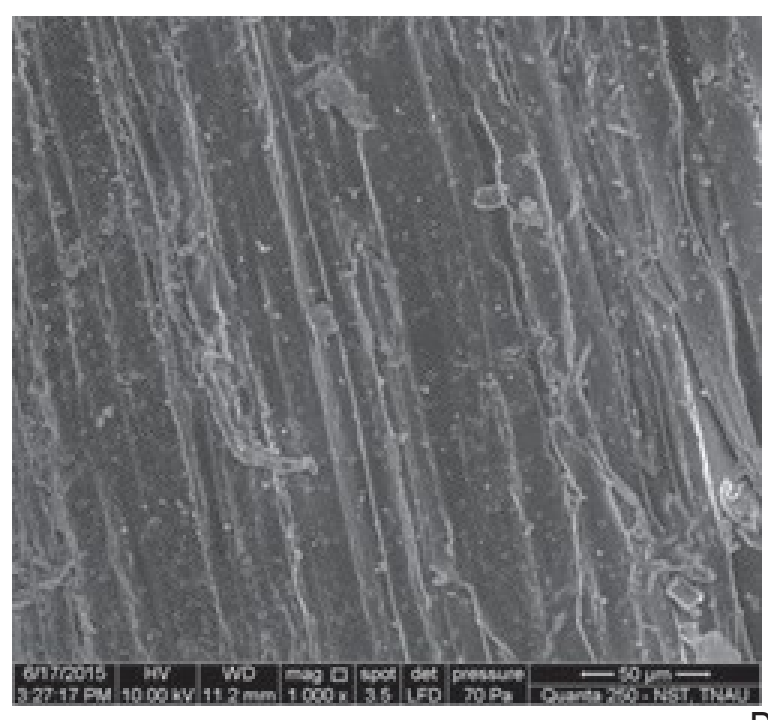

Pretreated biomass

Fig.1.SEM images of raw and pretreated biomass

\begin{tabular}{|c|c|c|c|c|}
\hline Particulars & $\begin{array}{l}\text { Ortho- } \\
\text { phosphoric acid }\end{array}$ & $\begin{array}{l}\text { Alkaline } \\
\text { hydrogen } \\
\text { peroxide }\end{array}$ & Lime & $\begin{array}{l}\text { Lime }+ \\
\text { hydrothermal } \\
\text { pre- treatment }\end{array}$ \\
\hline $\begin{array}{l}\text { Optimized } \\
\text { condition }\end{array}$ & $\begin{array}{l}16 \% \mathrm{H}_{3} \mathrm{PO}_{4} \\
\text { concen- } \\
\text { tration, } 12.5 \% \\
\text { solid } \\
\text { loading, } 121^{\circ} \mathrm{C} \\
3 \mathrm{~h}\end{array}$ & $\begin{array}{l}3 \% \mathrm{H}_{2} \mathrm{O}_{2} \\
\text { concentra- } \\
\text { tion } 10 \% \text { solid } \\
\text { loading, } \\
121^{\circ} \mathrm{C}, 2 \mathrm{~h}\end{array}$ & $\begin{array}{l}1.1 \% \text { lime, } \\
7.5 \% \text { total } \\
\text { solid } \\
\text { loading, } \\
121^{\circ} \mathrm{C}, 2 \mathrm{~h}\end{array}$ & $\begin{array}{c}16 \% \mathrm{H}_{3} \mathrm{PO}_{4} \\
\text { concentration, } \\
12.5 \% \text { solid } \\
\text { loading, } \\
160^{\circ} \mathrm{C}, \\
10 \mathrm{~min}\end{array}$ \\
\hline $\begin{array}{l}\text { Actual value } \\
\text { of Sugar } \\
\text { release }\end{array}$ & $\begin{array}{l}41.80 \mathrm{~g} / 100 \mathrm{~g} \text { of } \\
\text { biomass }\end{array}$ & $\begin{array}{l}17.65 \mathrm{~g} / 100 \mathrm{~g} \\
\text { of biomass }\end{array}$ & $\begin{array}{l}22.88 \\
\mathrm{~g} / 100 \mathrm{~g} \\
\text { of } \\
\text { biomass }\end{array}$ & $\begin{array}{l}0.11 \mathrm{~g} / 100 \mathrm{~g} \text { of } \\
\text { biomass }\end{array}$ \\
\hline $\begin{array}{l}\text { Predicted } \\
\text { value of Sug- } \\
\text { ar release }\end{array}$ & $\begin{array}{l}41.90 \mathrm{~g} / 100 \mathrm{~g} \text { of } \\
\text { biomass }\end{array}$ & $\begin{array}{l}17.56 \mathrm{~g} / 100 \mathrm{~g} \\
\text { of biomass }\end{array}$ & $\begin{array}{l}22.50 \\
\text { g/100g } \\
\text { of } \\
\text { biomass }\end{array}$ & $\begin{array}{l}0.107 \mathrm{~g} / 100 \mathrm{~g} \text { of } \\
\text { biomss }\end{array}$ \\
\hline Inhibitor (\%) & 4.02 & 1.21 & 0.48 & 0.07 \\
\hline $\begin{array}{l}\text { Crystallinity } \\
\text { index (Raw } \\
\text { bio- mass } \\
34.76 \text { ) } \\
\end{array}$ & 75.79 & 67.41 & 65.74 & 65.62 \\
\hline
\end{tabular}

actives were present in the pearl millet biomass showed that which were very easy to dissolve into the liquid fraction (Yang and Wyman, 2008). Cellulose content was high in raw biomass which may be due to genetic make. The lignin content of the pearl mil- let hay ranged from 22.01 to 27.57 per cent (Chen et al., 2007). Carbohydrate (cellulose and hemicellulose) content in the pearl millet biomass plays a major role the processing cost and ethanol production (Aden et al ., 2002). The comparison of acid, alkaline hydrogen

peroxide, lime and hydrothermal pretreatment was presented in Table 1.

The highest inhibitor was obtained for the op- timal condition which might be due to degradation of lignin fraction (Martin et al., 2007). Lignin frac- tions were oxidized and digested into formation of carboxylic acid and phenolic compounds. Acid pretreated hydrolysate with lime is widely used for the conditioning (Larsson et al., 1999) or neutralizing the hydrolysates which leads to precipitation of toxic sub-

stances (Van Zyl et al., 1988). In SEM analysis, drastic changes were observed in the surface of the pretreat- ed biomass. These results confirmed that the removal or 
defibration of individual fibres and expansion of the surface area Fig.1.). Coarse or spherical shape of the lignin particle precipitation was observed on the outer surface of the biomass (Selig et al., 2007). The Crl was high (Zhao et al., 2008) in all the pretreated biomass than in raw biomass because it has a lower content of hemicellulose and lignin, which are amor- phous in nature.

Conclusion

The foremost reason for increasing the use of ethanol is to reduce the emissions from combustion of conventional fuels, greenhouse gas emissions and dependence on fossil fuels. Therefore, the above de- picted pretreatment technologies forge a cost effective and feasible pretreatment method of pearl millet biomass to biofuel.

\section{Acknowledgments}

The authors kindly acknowledge the funding granted by INDO-US Joint clean energy research and development centre (JCERDC) under the scheme "US-India consortium for development of sustainable advanced lignocellulosic biofuel systems” (SALBS).

References

Aden, A., Ruth, M., Ibsen, K., Jecura, J., Neeves, K., Shee- han, J.,Wallace, B., Montague, L., Slayton, A., Lukas, J., 2002. Lignocellulosic biomass to ethanol process design and economics utilizing co-current dilute acid prehydrolysis and enzymatic hydrolysi for corn sto- ver, National Renewable Energy Laboratory, Haris group, Golden, CO and Seatle, WA.

Amarendar Reddy, A., Parthasarathy Rao, P., Yadav,O.P., Singh, I.P., Ardeshna, N.J., Kundu, K.K., Gupta, S.K., Gupta, Rajan Sharma, Sawargaonkar, G., Dharm Pal Malik, Moses shyam, D., K.Sammi Reddy.2013. Pros- pects for Kharif (Rainy season) and summer pearl millet in western India. ICRISAT, Paancheru, An- drapradesh, India.

Basavaraj, G., Parthasarathy Rao, P., Bhagavatula, S., Ahmed, W., 2010. Availability and utilization of pearl millet in India. Journal of SAT Agricultural Research. 8, 1-6.

Bray, H.C., Thorp, W.V., 1954. Analysis of phenolic com- pounds of interest in metabolism. Methods in Bio- chemical Analysis. 1, 27 - 32.

Chen, C., Shivappa, R.R.S., Chen, Ye., Wichman, D., Johnson, D., 2007. Potential of agricultural residues and hay for bioethanol production. Appl. Biochem. Biotech- nol. 142, 276-290.

Larsson, S., Reimann, A., Nilvebrant, N.Jonsson, J. 1999. Comparison of different methods for the detoxifica- tion of lignocellulose hydrolysates of spruce. Appl. Biochem. Biotechnol. 77,91-103.

Martin, C., Klinke, H., Marcet, M., Garcia, L., Hernandez, E., Thomsen, A.B., 2007. Study of the phenolic com- pounds formed during pretreatment of sugarcane bagasse by wet oxidation and steam explosion. Holz- forschung, 61, 483 - 487.

Miller, G.L., 1959. Use of dinitrosalicyclic acid reagent for determination of reducing sugar. Annal. Chem. 31, 426-428.

NREL (National Renewable Energy Laboratory), 2004, Index of GIS Data. Available at http://www.nrel.gov/gis/in-dex_of_gis.html.

Selig, M. J., Vimajala, S., Decker, S.R., Tucker, M.P., Himmel, M.E., Vinzant, T.B., 2007. Deposition of lignin drop- lets produced during dilute acid pretreatment of maize stems retards enzymatic hydrolysis of cellu- lose. Biotechnol. Prog. 23 (6), 13331339.

Van Zyl, C., Prior, B.A., Du Preez, J.C., 1988. Production of ethanol from sugarcane bagasse hemicellulose hy- drolyzate by Pichia stipitis. Appl. Biochem. Biotechnol. 17,357-369.

Yang, B., Wyman,C. E., 2008. Pretreatment: the key to un- locking low- cost cellulosic ethanol. Biofuels Bioprod. Bior. 2, 26-40.

Zhao, X.B., Wang, L., Liu, D.H., 2008. Peracetic acid pretreat- ment of sugarcane 619 bagasse for enzymatic hydro- lysis: a continued work. J. Chem. Technol. Biot. 83, 950-956. 